\title{
INFLUENCE OF SELECTED SOCIO-ECONOMIC FACTORS ON THE ADOPTION OF SUSTAINABLE AGRICULTURE TECHNOLOGIES IN MAIZE FARMING IN MZIMBA SOUTH, MALAWI
}

\author{
${ }^{* 1}$ Banda Owen Austin, ${ }^{1}$ Udoto Maurice Ongalo, ${ }^{2} \mathrm{Ng}$ 'eno Joel Kipkemoi \\ ${ }^{1}$ Department of Agricultural Education and Extension, \\ Faculty of Education and Community Studies, Egerton University, Kenya \\ ${ }^{2}$ Department of Curriculum, Instruction and Educational Management, \\ Faculty of Education and Community Studies, Egerton University, Kenya \\ *Corresponding Author
}

DOI: 10.46609/IJAER.2020.v06i02.001 URL: https://doi.org/10.46609/IJAER.2020.v06i02.001

\begin{abstract}
Sustainable Agriculture Technologies (SATs) contribute significantly to increasing maize production in Malawi; through improving soil fertility, addressing the effects of land degradation, and increasing the adaptive capacity of farmers to climate change and variability. In an effort to optimize the benefits of SATs, the Government of Malawi and other relevant stakeholders in the agriculture sector promote SATs across all districts. Despite the efforts of the stakeholders in scaling up SATs, the adoption of the technologies in maize farming remains low in Mzimba South in Malawi. Therefore, a study was carried out from July to September 2019 to investigate the influence of selected socio-economic factors on the adoption of SATs in maize farming among the small-scale producers in Mzimba South. A multi-stage sampling method was used to select a sample of 132 small-scale maize producing households. A researcheradministered questionnaire was used to collect data. The data was analyzed using t-tests, chisquare tests, and multivariate probit, ordered probit and ordinary least square (OLS) models at $\alpha$ level of .05. The study established that household size, education level, arable land size and livestock ownership significantly influence the adoption of SATs. The results implied that the producers should be trained in the timely and proper implementation of the SATs. In addition, relevant stakeholders should promote livestock multiplication interventions; while promoting effective crop-livestock integration measures.
\end{abstract}


International Journal of Agriculture and Environmental Research

ISSN: 2455-6939

Volume: 06, Issue: 02 "March-April 2020"

Keywords: Adoption, Influence, Maize, Malawi, Socio-economic factors, Sustainable agriculture technologies

\section{INTRODUCTION}

Globally, sustainable agricultural technologies (SATs) are used as land management practices that work with natural processes to sustain agricultural production by conserving resources, reducing waste and environmental impacts, and promoting resilience and self-regulating mechanisms of agro-ecosystems (MacRae, Hill, Henning \& Mehuys, 1989). Similarly, SATs are being applied in many African countries to intensify crop and livestock production to meet the population's requirements; in a manner that reduces adverse environmental impacts and maximizes efficient utilization of ecosystem services for the benefit of Africans. The technologies rely on organic farm inputs, agro-ecological processes for fixation and re-cycling of resources, and natural interdependencies among organisms. In addition, SATs contribute significantly to increasing capacity of farmers in mitigating impacts of environmental degradation and improving adaptability to the impacts. The widely promoted SATs in Africa include agroforestry, conservation agriculture, organic farming, integrated pest and weed management, rain-water harvesting practices, and drought tolerant cropping (Pretty, Toulmin \& Williams, 2011).

Despite the availability of agricultural agencies promoting SATs at all levels, the adoption of the technologies remains unsatisfactory in both developed and developing countries (Barrow, Chan \& Masron, 2010; Food and Agriculture Organization [FAO], 2017). The situation is evidenced by the low average percentage of the total area of land under sustainable agriculture. By 2012, the average percentage of land under sustainable agriculture was at 38.5 in North and South America, while the combined percentage in African and European countries was at 1 (Friedrich, Derpsch \& Kassam, 2012). Likewise, adoption in Malawi is still low despite the proven benefits of the SATs among farmers. For instance, the arable land under SATs in Mzimba South was at 9.3\% in 2016 (M'mbelwa District Council [MDC], 2017). According to Ngwira, Johnsen, Aune, Mekuria and Thierfelder (2014), low adoption of SATs limits the capacity of small-scale producers to address land degradation and adapt to the negative effects of climate change and variability.

A significant number of studies have been conducted to identify or investigate factors which influence adoption of SATs (Kassie, Zikhali, Manjur \& Edwards, 2009; Prager \& Posthumus, 2010). However, the studies have not been exhaustive enough on key factors influencing adoption of the technologies in maize production across different agro-ecological zones in Malawi (Ngwira et al., 2014). Inadequate understanding of the potential determinants of adoption limits the capacity of extension agencies, research institutions and farmers in 
International Journal of Agriculture and Environmental Research

ISSN: 2455-6939

Volume: 06, Issue: 02 "March-April 2020"

establishing the current status of adoption as well as formulating measures to scale up the use of SATs in maize farming (Thierfelder, Ngwira, Eash \& Lambert, 2013). Socio-economic factors are among the key aspects influencing farmers' decisions to adopt SATs across the world. However, there is a lack of evidence on the level of the influence of the factors on SATs adoption in maize production in Mzimba South.

The study was based on the Random Utility Theory (RUT). The theory establishes the rationality of individuals or groups in making decisions about their choices from an available set of alternatives. People select courses of actions to address problems on the basis of realized or expected benefits relating to each of the available alternatives (Manski, 1977). The theory describes the probability of an observable preference of a person as a result of interactions among identified and unidentified factors in an environment. In this case, the individual's choice is attributable to unobserved advantages realized from his or her choice against its competing alternatives (Azari, Parks \& Xia, 2012). In line with the RUT, the study recognized that adoption decisions about SATs were intrinsically multivariate as farmers were required to select specific technologies from an interrelated set of options (Dorfman, 1996). Thus, farmers were inclined to adopt SATs whose advantages outweighed those of conventional or substitute technologies. The theory was applied as the basis for modeling of adoption decisions among the small-scale maize producers; as a result of the possible influence of selected socio-economic factors (Teklewold, Kassie \& Shiferaw, 2013). Specifically, the factors were age, years of experience in maize farming, household size, sex of household head, education level, arable land size, income level, sources of farm labour and livestock ownership (as measured in Total Livestock Units). The study considered seven widely promoted SATs in Malawi, namely; manure making and utilization, agroforestry, pit-planting, mulching, reduced tillage, crop rotation (with the inclusion of leguminous crops), and crop residues incorporation (Ngwira et al., 2014; Sosola, Akinnifesi, Sileshi \& Ajayi, 2011). The following two null hypotheses were tested to understand the adoption of the seven selected SATs:

(i) There is no statistically significant difference in the socio-economic characteristics between adopters and non-adopters of SATs among the small-scale maize producers in Mzimba South, Malawi.

(ii) There is no statistically significant influence of selected socio-economic factors on the adoption of SATs among the small-scale maize producers in Mzimba South, Malawi.

\section{METHODOLOGY}

\subsection{Research Design}


The study applied a concurrent triangulation mixed design in which both quantitative and qualitative data were collected, analyzed and interpreted within the same period. The design was used to validate, understand and explain the relationships among the variables of the study. In terms of volume and frequency of use, the quantitative data set was dominant over the qualitative one. The two data sets were collected and analyzed separately, but were subsequently integrated at the interpretation stage to provide an in-depth understanding of the findings in line with the two hypotheses (Creswell, Plano Clark, Gutmann \& Hanson, 2003).

\subsection{Study Location}

The study was carried out in Mzimba South of Mzimba District in Malawi. Mzimba is the largest district in Malawi with a total area of 10,382 square kilometres. The district is located at coordinates $-11^{\circ} 29^{\prime} 59.99^{\prime \prime} \mathrm{S} 33^{\circ} 29^{\prime} 59.99^{\prime \prime} \mathrm{E}$. It is situated at a distance of 280 kilometres to the North of Lilongwe (the capital city of Malawi). Mzimba borders Zambia to the West, Rumphi District to the North, Nkhatabay District to the East, Kasungu District to the South and Nkhotakota District to the South East. In the agriculture sector, the areas of the district are administratively divided into Mzimba North and Mzimba South. Mzimba South is further divided into 11 agro-ecological areas called Extension Planning Areas (EPAs) as shown in Figure 1. Depending on the area and population of the EPAs, each EPA has a number of Sections. Mzimba South has 106 Sections in total. The population of Mzimba South comprises $70 \%$ small-scale producers who grow maize as the main staple crop. The area experiences inadequate and sporadic rains during some seasons. This situation, coupled with degraded soils, has led to an increase of agricultural extension agencies promoting SATs (MDC, 2017). 
International Journal of Agriculture and Environmental Research

ISSN: 2455-6939

Volume: 06, Issue: 02 "March-April 2020"

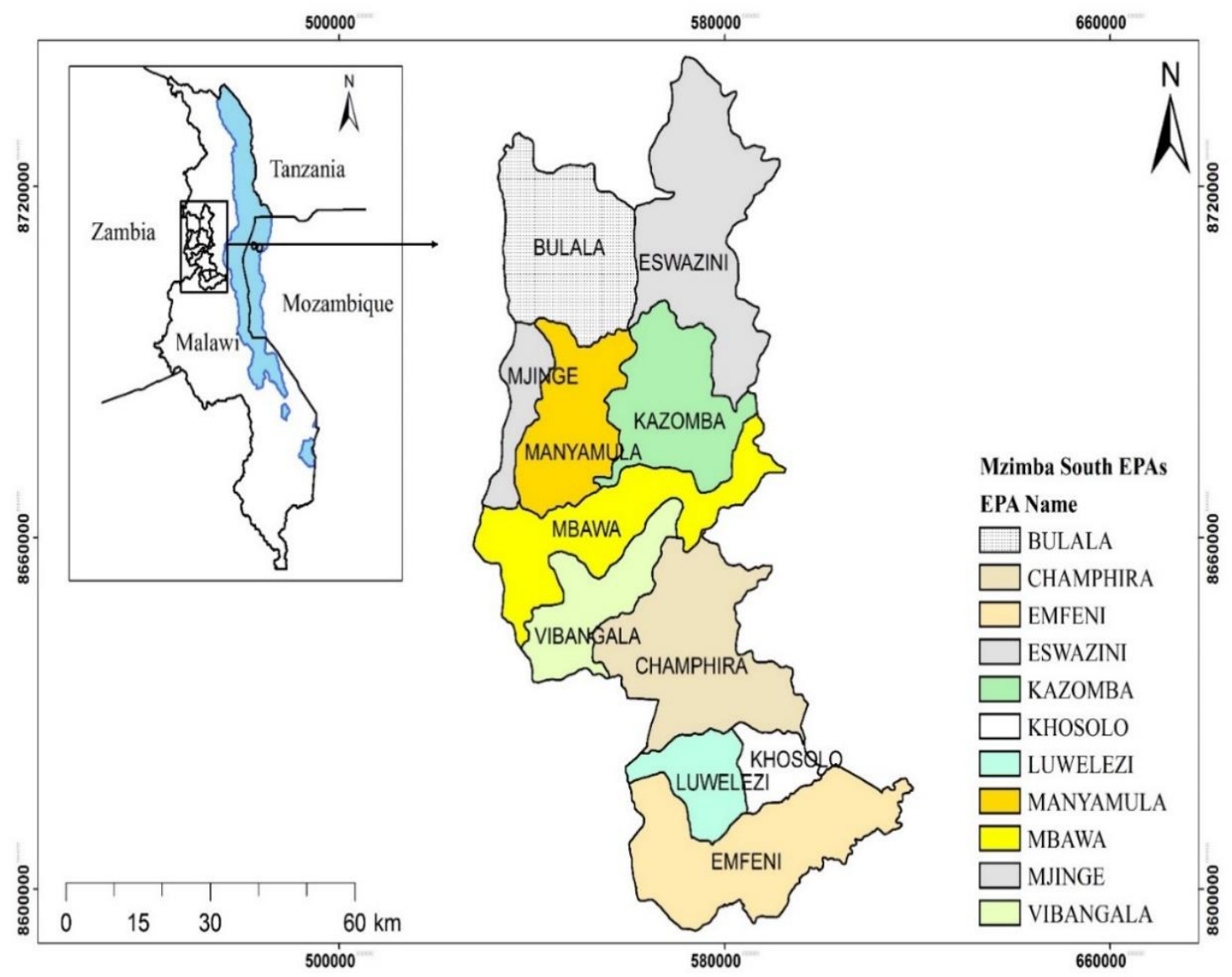

Source: Author (2019)

Figure 1: Map of Mzimba South in Malawi

\subsection{Sampling Procedure and Sample Size}

The study used a multi-stage sampling procedure in which a combination of purposive and simple random sampling techniques were applied. Mzimba South was purposively selected on the basis that it is among the areas in Malawi with high levels of arable land degradation (Njoloma, Sileshi, Sosola, Nalivata, \& Nyoka, 2016). Simple random sampling (using bucket method) was used to identify six EPAs from a total of 11 EPAs. The selection of 132 household heads was conducted by a simple random sampling technique in which a table of random number was used (Mugenda \& Mugenda, 2003; Nassiuma, 2000). The sample was drawn from the target population of 156,670 small-scale maize producing households in Mzimba South. The sample was proportionately spread across the six EPAs as shown in Table 1. 
International Journal of Agriculture and Environmental Research

ISSN: 2455-6939

Volume: 06, Issue: 02 "March-April 2020"

Table 1: Sample distribution of small-scale maize farming households by EPA

\begin{tabular}{lc}
\hline EPA name & Sample size \\
\hline Luwerezi & 17 \\
Champhira & 29 \\
Mbawa & 27 \\
Manyamula & 25 \\
Eswazini & 22 \\
Mjinge & 12 \\
\hline Total & 132 \\
\hline Source: Own survey (2019) &
\end{tabular}

\subsection{Data Collection}

A researcher-administered questionnaire was used to collect qualitative and quantitative data from the sampled 132 household heads. The instrument was pretested and assessed for internal consistency using Cronbach's alpha method (Mugenda \& Mugenda, 2003). The questionnaire's Cronbach's $\alpha$ coefficient was adjusted to .71 .

\subsection{Data Analysis}

The statistical computer packages of SPSS and STATA were used to analyze the data. Particularly, means, percentages and standard deviations were used to describe the socioeconomic attributes of the sample. T-tests and chi-square tests were applied to compare the adopters and non-adopters based on the selected socio-economic factors. The study also applied a deductive approach to analyze qualitative data by grouping and coding responses basing on the similarities, differences and trends across the respondents. The study used multivariate, ordered and OLS models to determine the influence of the selected socio-economic factors on the adoption of the seven SATs.

Multivariate Probit Model. The model was used to predict probabilities of adoption decisions relating to each type of the seven SATs; as influenced by the selected nine socio-economic factors. The basis for the application of model was that farmers selected SATs (or their combinations) from a related set of technologies to maximize the benefits from maize production (Dorfman, 1996). The model can be expressed in a probability form as shown by equation 1 .

$\mathrm{P}\left(\mathrm{Y}_{\mathrm{is}}=1 \mid \mathrm{X}_{\mathrm{i}}\right)=\mathrm{P}\left(\mathrm{X}_{\mathrm{i}}^{\prime} \beta_{\mathrm{s}}+\varepsilon_{\mathrm{i}}>0 \mid \mathrm{X}_{\mathrm{i}}\right)$

$(s=M M U, M C, P P, A G F, C R, C R I, R T)$ 
International Journal of Agriculture and Environmental Research

ISSN: 2455-6939

Volume: 06, Issue: 02 "March-April 2020"

Where $i$ represents small-scale maize producing households and $s$ are the specific SATs of manure making and utilization $(M M U)$, mulching $(M C)$, pit-planting $(P P)$, agroforestry $(A G F)$, crop rotation $(C R)$, crop residues incorporation $(C R I)$, and reduced tillage $(R T)$. $\left(\boldsymbol{X}_{\boldsymbol{i}}\right)$ represents the observable household socio-economic characteristics, $\left(\varepsilon_{\mathbf{i}}\right)$ represents the unobservable factors and $\beta_{\mathrm{s}}$ represents standardized coefficients of the predictor variables.

Ordered Probit Model. An ordered probit model was used to determine the influence of the nine socio-economic factors on the level of adoption (based on the number of SATs adopted by the producers). The producers were classified into different adoption levels based on the number of adopted SATs as (i) low adopters (for zero to two SATs), (ii) average adopters (for three to four SATs) and (ii) high adopters (for five to seven SATs). This classification was based on the approach used by Mzuzu Agricultural Development Division (MZADD) in Malawi for characterizing small-scale producers participating in sustainable agriculture. The model was used to predict the adoption level as an ordinal dependent variable $\left(\mathrm{L}^{*}\right)$. The application of the model implied that households would adopt additional SATs (thus moving towards higher adoption level) if the benefits realized from adopting more SATs outweighed those associated with adopting fewer SATs (McKelvey \& Zavoina, 1975). The ordered probit model is shown in equation 2.

$\mathrm{P}\left(L_{\mathrm{i}}=1 \mid \mathrm{X}_{\mathrm{i}}\right)=\mathrm{P}\left(\mathrm{X}_{\mathrm{i}}^{\prime} \beta+\varepsilon_{\mathrm{i}}>0 \mid \mathrm{X}_{\mathrm{i}}\right)$

Where $\mathbf{X}_{\mathbf{i}}$ represents a vector of household attributes, $\boldsymbol{\beta}$ is a vector of predicted parameters, and $\varepsilon_{\mathbf{i}}$ represents unobserved factors.

Ordinary Least Squares Model. An OLS model was used to establish the influence of the selected socio-economic factors on the area of arable land (in acres) under the SATs. The OLS regression equation is shown as equation 3 .

$\hat{y}_{i}=\hat{\alpha}+\beta_{i} x_{i}+\hat{\varepsilon}_{i}$

Where: $\hat{y}_{\mathrm{i}}$ is a change in the arable land area

$\hat{\alpha}$ is an estimator of the intercept coefficient

$\beta_{\mathrm{i}}$ is an estimator of the slope coefficient

$\mathrm{x}_{\mathrm{i}}$ is the predictor variable of the ith household

$\hat{\varepsilon}_{i}$ is the residual for the ith household 
The socio-economic factors used in the multivariate probit, ordered probit and OLS models are described as:

$\mathrm{X}_{1}=$ Age of the household head (continuous variable; age in years)

$\mathrm{X}_{2}=$ Household size (discrete variable; number of household members)

$\mathrm{X}_{3}=$ Education level (Continuous variable; years of formal schooling)

$\mathrm{X}_{4}=$ Arable land size (Continuous variable; area in acres)

$\mathrm{X}_{5}=$ Farming experience (Continuous variable; years of experience in maize farming)

$\mathrm{X}_{6}=$ Household income (Continuous variable; amount of yearly income in Malawi Kwacha)

$\mathrm{X}_{7}=$ Livestock ownership (Continuous variable; number of livestock owned in TLUs)

$\mathrm{X}_{8}=$ Sex (Dummy variable; sex of household head)

$\mathrm{X}_{9}=$ Farm labour source (Dummy variable; use or non-use of hired farm labour)

\section{RESULTS AND DISCUSSION}

\subsection{Comparison of the Characteristics of the Adopters and Non-adopters of SATs}

The study tested the first null hypothesis that there is no statistically significant difference in the socio-economic characteristics between adopters and non-adopters of SATs among the smallscale maize producers in Mzimba South. The null hypothesis was rejected as the producers were found to be different in terms of the age, household size, education level, arable land size, farming experience, household income, livestock ownership and sex of household heads ( $\mathrm{p}<$ $.05)$.

\subsubsection{Age of the household head}

The overall mean age of the household heads was 49.0 years $(\mathrm{SD}=9.5)$. The mean age of the adopters of SATs was 46.5 while those of non-adopters was 62.3. The results of two-tailed t-tests for independent samples showed statistically significant differences of the mean ages between the adopters and non-adopters of manure, agroforestry, pit-planting and mulching $(\mathrm{p}<.05)$ as shown in Table 2. The results indicated that more of the younger farmers adopted the four SATs (manure, agroforestry, pit-planting and mulching) than did their elderly counterparts. Since the four SATs have attributes of labour intensiveness and longer time lags to yield benefits, the resistance of older farmers to adopt the technologies could be attributed to their short-term career goals, declining energy levels and risk-averse behaviour (Murendo et al., 2016). A similar study 
conducted by Musara, Chimvuramahwe and Borerwe (2012) revealed that older farmers exhibited a relatively conservative behaviour of avoiding perceived risks and uncertainties associated with SATs in Zimbabwe. These farmers opted for conventional practices that were regarded as less labour-intensive, low cost and those that took shorter time lags to yield results (such as use of inorganic fertilizers).

Table 2: Age of household head and SATs adoption $(n=132)$

\begin{tabular}{lcccc}
\hline SATs & \multicolumn{2}{c}{ Means of ages } & t-value & \multirow{2}{*}{ Sig. } \\
\cline { 2 - 3 } & Adopters & Non-adopters & & \\
\hline Manure making and utilization & 44.8 & 59.8 & $-6.076^{*}$ & .000 \\
Agroforestry & 45.5 & 52.0 & $-2.610^{*}$ & .010 \\
Pit-planting & 43.2 & 53.0 & $-4.075^{*}$ & .000 \\
Mulching & 44.7 & 56.0 & $-4.660^{*}$ & .000 \\
Reduced tillage & 44.7 & 49.5 & -1.668 & .110 \\
Crop rotation & 46.6 & 49.6 & -1.102 & .276 \\
Crop residue incorporation & 47.4 & 50.1 & -1.123 & .263 \\
\hline
\end{tabular}

Source: Own survey (2019)

$*$ indicates the statistical significance at $\mathrm{p}<.01$

\subsubsection{Household size}

The mean size of the sampled households was 6 members $(\mathrm{SD}=2)$. The means of household sizes of adopters and non-adopters were 6 and 7 respectively. The results of t-tests across the seven SATs indicated a statistically significant difference in household sizes between adopters and non-adopters of only mulching $(\mathrm{p}<.05)$ as shown in Table 3.

Table 3: Household size and SATs adoption $(n=132)$

\begin{tabular}{lcccc}
\hline SATs & \multicolumn{2}{c}{ Means of household sizes } & t-value & \multirow{2}{*}{ Sig. } \\
\cline { 2 - 3 } & Adopters & Non-adopters & & \\
\hline Manure making and utilization & 6.0 & 6.7 & -1.832 & .069 \\
Agroforestry & 5.9 & 6.4 & -1.303 & .195 \\
Pit-planting & 6.1 & 6.2 & -0.371 & .711 \\
Mulching & 6.7 & 5.8 & $-2.568^{* *}$ & .011 \\
Reduced tillage & 6.9 & 6.1 & 1.594 & .113 \\
Crop rotation & 6.8 & 6.0 & 1.818 & .071 \\
Crop residue incorporation & 6.1 & 6.2 & -1.303 & .195 \\
\hline
\end{tabular}

Source: own survey (2019)

$* *$ indicates the statistical significance at $\mathrm{p}<.05$ 
The statistical tests results revealed that more households with relatively larger sizes $(M=7)$ had adopted mulching than those with smaller sizes $(M=6)$. This disparity could be explained by the increased level of flexibility to share mulching-related activities among members of larger households. Mulching remains an example of SATs which involve time-consuming and strenuous activities (Abdul-Hanan, Ayamga \& Donkoh, 2014). Since household members remain the main and cheap source of labour in Mzimba South, operations such as collection, storage and laying of mulch (usually maize stovers) are easily shared and undertaken within larger households.

\subsubsection{Education level}

The mean years of formal schooling among the household heads was $7.0(\mathrm{SD}=3.2$ ). This overall mean is equivalent to Standard 7 of Malawi's 8-4-4 Education System. Particularly, the distribution of means of formal schooling years for SATs adopters and non-adopters were 7.8 (Standard 7) and 3.0 (Standard 3) respectively. The results of two-tailed t-tests showed significant differences of the mean number of years between the two household categories for all SATs, $\mathrm{p}<.05$ (Table 4); thereby implying that adopters had more years of formal schooling than non-adopters. These findings conform to those of Abdulai and Huffman (2014), in which high level of SATs adoption among more educated farmers was attributed to their increased likelihood of understanding and utilization of SATs as compared to their less educated counterparts.

Table 4: Years of formal schooling and SATs adoption $(\mathbf{n}=132)$

\begin{tabular}{lcccc}
\hline SATs & \multicolumn{2}{c}{ Mean years of formal schooling } & t-value & \multirow{2}{*}{ Sig. } \\
\cline { 2 - 3 } & Adopters & Non-adopters & & \\
\hline Manure making and utilization & 8.0 & 4.3 & $7.075^{*}$ & .000 \\
Agroforestry & 8.2 & 5.9 & $4.397^{*}$ & .000 \\
Pit-planting & 8.7 & 5.9 & $6.063^{*}$ & .000 \\
Mulching & 9.1 & 6.5 & $3.915^{*}$ & .000 \\
Reduced tillage & 9.2 & 6.7 & $3.992^{*}$ & .001 \\
Crop rotation & 8.3 & 4.9 & $6.416^{*}$ & .000 \\
Crop residue incorporation & 7.7 & 6.5 & $2.342^{* *}$ & .021 \\
\hline
\end{tabular}

Source: Own survey (2019)

$*$ and $* *$ indicate the statistical significance at $\mathrm{p}<.01$ and $\mathrm{p}<.05$ respectively 
International Journal of Agriculture and Environmental Research

ISSN: 2455-6939

Volume: 06, Issue: 02 "March-April 2020"

\subsubsection{Arable land size}

As regards the arable land size, the findings indicated that the average land size for all the households was 3.3 acres $(\mathrm{SD}=1.3)$. In particular, the acreage averages of the adopters and nonadopters were 3.5 and 2.1 respectively.

Table 5: Arable land size and SATs adoption $(n=132)$

\begin{tabular}{|c|c|c|c|c|}
\hline \multirow[t]{2}{*}{ SATs } & \multicolumn{2}{|c|}{ Arable land size (Acres) } & \multirow[t]{2}{*}{ t-value } & \multirow[t]{2}{*}{ Sig. } \\
\hline & Adopters & Non-adopters & & \\
\hline Manure making and utilization & 3.5 & 2.6 & $4.627 *$ & .000 \\
\hline Agroforestry & 3.7 & 2.9 & $4.194 *$ & .000 \\
\hline Pit-planting & 3.6 & 3.0 & $2.485^{* *}$ & .014 \\
\hline Mulching & 4.2 & 3.0 & $4.602 *$ & .000 \\
\hline Reduced tillage & 4.2 & 3.2 & $2.959 *$ & .004 \\
\hline Crop rotation & 3.7 & 2.6 & $5.181 *$ & .000 \\
\hline Crop residue incorporation & 3.8 & 2.9 & $4.716^{*}$ & .000 \\
\hline
\end{tabular}

Source: Own survey (2019)

$*$ and $* *$ indicate the statistical significance at $\mathrm{p}<.01$ and $\mathrm{p}<.05$ respectively

The output of t-tests across all technologies showed statistically significant differences of acreage averages between the two adoption categories, $\mathrm{p}<.05$ (Table 5). This situation inferred that SATs adopters had larger arable farm plots as compared to non-adopters in Mzimba South. The findings supported those of previous studies in which larger land holdings increased the flexibility of households to use significant portions of farm plots for sustainable cropping; hence increasing chances of adopting SATs (Emuh \& Ofuoku, 2011; Lambert \& Ozioma, 2012; Murendo et al., 2016).

\subsubsection{Farming experience}

The study also found out that the overall mean of the farmers' years of experience in maize farming was 24.5 ( $\mathrm{SD}=13.2$ ). Specifically, the adopters had an overall mean of 22.2 while the non-adopters had a mean of 36.4. The results of t-tests indicated insignificant differences of years of experience between adopters and non-adopters of reduced tillage, crop rotation and crop residue incorporation (Table 6). On the other hand, the t-tests showed significant differences of years of experience between adopters and non-adopters of manure, agroforestry, pit-planting and mulching technologies $(\mathrm{p}<.05)$; hence, implying that less experienced farmers (those with fewer years of experience) adopted the four SATs more than the experienced farmers. 
International Journal of Agriculture and Environmental Research

ISSN: 2455-6939

Volume: 06, Issue: 02 "March-April 2020"

Table 6: Years of farming experience and SATs adoption $(n=132)$

\begin{tabular}{lcccc}
\hline SATs & \multicolumn{2}{c}{ Means of farming experience years } & t-value & \multirow{2}{*}{ Sig. } \\
\cline { 2 - 3 } & Adopters & Non-adopters & & \\
\hline Manure making and utilization & 21.1 & 33.0 & $-5.039^{*}$ & .000 \\
Agroforestry & 21.8 & 26.7 & $-2.106^{* *}$ & .037 \\
Pit-planting & 19.2 & 28.0 & $-3.970^{*}$ & .000 \\
Mulching & 21.1 & 29.9 & $-3.866^{*}$ & .000 \\
Reduced tillage & 20.9 & 24.9 & -1.054 & .294 \\
Crop rotation & 23.0 & 25.0 & -0.905 & .367 \\
Crop residue incorporation & 23.1 & 25.4 & -0.969 & .334 \\
\hline
\end{tabular}

Source: Own survey (2019)

$*$ and $* *$ indicate the statistical significance at $\mathrm{p}<.01$ and $\mathrm{p}<.05$ respectively

Similar to the relationship between age and adoption discussed earlier on in this sub-section, older farmers who were also more experienced, had a low level of acceptance of labour-intensive and gradually-rewarding SATs such as manure, agro-forestry, pit-planting and mulching (Musara et al., 2012). Despite the assertion that farming experience increases the likelihood of adopting SATs (Kassie, Teklewold, Jaleta, Marenya \& Erenstein, 2015), the results established a strong positive correlation between farming experience and age, $\mathrm{r}(130)=0.84, \mathrm{p}=.000$. Thus, regardless of a higher level of farming experience, older farmers were relatively resistant to adopt SATs due to their short-term career objectives, declining energy levels and risk-averse behaviour (Murendo et al., 2016; Odendo, Obare \& Salasya, 2011).

\subsubsection{Household income}

The yearly income of the households had an overall average of MK198,704.55 (SD = MK123,669.21). Particularly, the yearly income average of the adopters was MK216,828.83 while that of non-adopters was MK102,904.76. Two-tailed t-tests showed that adopters had a higher yearly income than non-adopters throughout all SATs, $\mathrm{p}<.05$ (Table 7). 
International Journal of Agriculture and Environmental Research

ISSN: 2455-6939

Volume: 06, Issue: 02 "March-April 2020"

Table 7: Average yearly income (in Malawi Kwacha) and SATs adoption $(n=132)$

\begin{tabular}{|c|c|c|c|c|}
\hline \multirow[t]{2}{*}{ SATs } & \multicolumn{2}{|c|}{ Average yearly income (MK) } & \multirow[t]{2}{*}{ t-value } & \multirow[t]{2}{*}{ Sig. } \\
\hline & Adopters & Non-adopters & & \\
\hline Manure making and utilization & $232,452.63$ & $112,054.05$ & $8.102 *$ & .000 \\
\hline Agroforestry & $230,491.80$ & $171,394.37$ & $2.737 *$ & .007 \\
\hline Pit-planting & $240,222.22$ & $169,961.54$ & $3.331 *$ & .001 \\
\hline Mulching & $271,423.08$ & $180,867.92$ & $3.485^{*}$ & .001 \\
\hline Reduced tillage & $269,214.29$ & $190,338.98$ & $2.293 * *$ & .023 \\
\hline Crop rotation & $237,121.95$ & $135,700.00$ & $5.810^{*}$ & .000 \\
\hline Crop residue incorporation & $234,333.33$ & $174,038.46$ & $2.827 *$ & .005 \\
\hline
\end{tabular}

Source: Own survey (2019)

$*$ and $* *$ indicate the statistical significance at $\mathrm{p}<.01$ and $\mathrm{p}<.05$ respectively

Since sustainable farming is an investment that requires financial resources to acquire factors of production such as farm inputs, labour and land; farmers with higher incomes were likely to be in the adopters' category. In this case, the results complied with the findings from Tey (2013) and Goeb (2013), in which adoption of SATs was partly attributed to the financial capacity of farmers to meet the costs associated with implementation of these technologies.

\subsubsection{Livestock ownership}

The overall mean of livestock units raised by the households was 2.2 ( $\mathrm{SD}=1.8)$. The results showed that the means of TLUs for adopters and non-adopters were 2.5 and 0.3 respectively.

Table 8: Total livestock units and SATs adoption $(n=132)$

\begin{tabular}{lcccc}
\hline SATs & \multicolumn{2}{c}{ Means of TLUs } & t-value & \multirow{2}{*}{ Sig. } \\
\cline { 2 - 3 } & Adopters & Non-adopters & & \\
\hline Manure making and utilization & 2.9 & 0.3 & $7.377^{*}$ & .000 \\
Agroforestry & 3.0 & 1.5 & $2.804^{*}$ & .006 \\
Pit-planting & 3.4 & 1.3 & $3.772^{*}$ & .000 \\
Mulching & 4.2 & 1.7 & $3.030^{*}$ & .005 \\
Reduced tillage & 5.1 & 1.8 & $4.030^{*}$ & .000 \\
Crop rotation & 3.0 & 0.8 & $4.754^{*}$ & .000 \\
Crop residue incorporation & 3.5 & 1.2 & $4.075^{*}$ & .000 \\
\hline
\end{tabular}

Source: Own survey (2019)

$*$ and $* *$ indicate the statistical significance at $\mathrm{p}<.01$ and $\mathrm{p}<.05$ respectively

The findings established that SATs adopters had more livestock units as compared to nonadopters, $\mathrm{p}<.05$ (Table 8 ). These results were mainly attributable to the organic manure which 
is made from livestock fecal matter, and the increased level of investment in sustainable farming as a result of livestock sells (Kassie, Jaleta, Shiferaw, Mmbando \& Mekuria, 2013).

\subsubsection{Sex of household head}

The study had the percentages of male-headed and female-headed households of 57 and 43 respectively. The findings revealed that there was a significant association between sex of household head and SATs adoption only in mulching technology, $\mathrm{p}<.05$ (Table 9). Thus, there were more adopters of mulching among male-headed households than were within the group of female-headed households.

Table 9: Association between sex of household head and SATs adoption $(n=132)$

\begin{tabular}{llcccc}
\hline SATs & Sex & \multicolumn{2}{c}{ Percentages of respondents } & \multirow{2}{*}{$\chi^{2}$ value } & \multirow{2}{*}{ Sig. } \\
\cline { 3 - 4 } Manure making and utilization & Male & 42 & 15 & 0.160 & .689 \\
& Female & 30 & 13 & & \\
Agroforestry & Male & 27 & 30 & 0.223 & .636 \\
& Female & 19 & 24 & & \\
Pit-planting & Male & 23 & 34 & 0.059 & .807 \\
Mulching & Female & 18 & 25 & & \\
\multirow{5}{*}{ Reduced tillage } & Male & 15 & 42 & $5.334 * *$ & .021 \\
& Female & 5 & 39 & & \\
Crop rotation & Male & 7 & 50 & 0.356 & .551 \\
& Female & 4 & 39 & & \\
Crop residue incorporation & Male & 36 & 21 & 0.022 & .882 \\
& Female & 26 & 17 & & \\
& Male & 24 & 33 & 0.222 & .638 \\
\hline
\end{tabular}

Source: own survey (2019)

** indicates the statistical significance at $\mathrm{p}<.05$

Culturally, farming communities in Mzimba South are patrilineal with most of their arable land under customary tenure system. The land is predominantly regarded as free grazing area after harvesting of crops. In addition, men in the communities have more decision-making power related to the use of land resources. Therefore, beside the low level of resource endowments among most of the female-headed households, the low adoption level of mulching among women farmers in Mzimba South could be attributed to the less control of this gender category over the production, use and preservation of crop residues biomass (Lovo, 2016). 


\subsubsection{Sources of farm labour in maize farming}

The study identified household members and hired labour as the two main sources of labour used in maize farming. Household members were used by all the sampled households whereas hired labour was used by 29 percent of the households (Table 10). The findings showed that there was a significant number of adopters among a group of households which had used hired labour for manure, agroforestry, pit-planting, mulching and crop residues incorporation $(p<.05)$. These results were consistent with those in previous studies which attributed a positive relationship between the use of hired labour and adoption of SATs to the financial capacity of farmers. In the studies, the financial capacity of some farmers enabled them to hire additional human power to off-set and compensate for labour-intensiveness and time-consuming attributes of most of the SATs (Abdul-Hanan et al., 2014; Ngwira et al., 2014).

Table 10: Association between main sources of labour and SATs adoption $(n=132)$

\begin{tabular}{|c|c|c|c|c|c|}
\hline \multirow[t]{2}{*}{ SATs } & \multirow[t]{2}{*}{ Labour sources } & \multicolumn{2}{|c|}{ Percentages of respondents } & \multirow[t]{2}{*}{$\chi^{2}$ value } & \multirow[t]{2}{*}{ Sig. } \\
\hline & & Adopters & Non-adopters & & \\
\hline \multirow{2}{*}{ Manure making } & Household members & 72 & 28 & - & - \\
\hline & Hired labour & 24 & 5 & $3.963 * *$ & .046 \\
\hline \multirow{2}{*}{ Agroforestry } & Household members & 46 & 54 & - & - \\
\hline & Hired labour & 26 & 12 & $3.759 * *$ & .048 \\
\hline \multirow[t]{2}{*}{ Pit-planting } & Household members & 41 & 59 & - & - \\
\hline & Hired labour & 16 & 13 & $4.548 * *$ & .033 \\
\hline \multirow[t]{2}{*}{ Mulching } & Household members & 20 & 80 & - & - \\
\hline & Hired labour & 9 & 20 & $4.763 * *$ & .029 \\
\hline \multirow[t]{2}{*}{ Reduced tillage } & Household members & 11 & 89 & - & - \\
\hline & Hired labour & 5 & 24 & 3.437 & .064 \\
\hline \multirow[t]{2}{*}{ Crop rotation } & Household members & 62 & 38 & - & - \\
\hline & Hired labour & 21 & 8 & 3.032 & .082 \\
\hline Crop residues & Household members & 41 & 59 & - & - \\
\hline incorporation & Hired labour & 18 & 11 & $10.927^{*}$ & .001 \\
\hline
\end{tabular}

Source: Own survey

Note. Chi-square value for household members was not computed because the factor was constant across all households

$*$ and $* *$ indicate the statistical significance at $\mathrm{p}<.01$ and $\mathrm{p}<.05$ respectively

\subsection{Determination of the Influence of Selected Socio-economic Factors on SATs Adoption}

The second null hypothesis that there is no statistically significant influence of selected socioeconomic factors on the adoption of SATs was also tested. In the analysis, farming experience was entirely eliminated because of its strong positive correlation with age, $r(130)=.84, p=.000$ (multicollinearity). The findings showed that both multivariate and ordered probit model 
analyses using maximum likelihood estimation gave statistically significant Wald test results for socio-economic factors. The probit model results indicated that all regression coefficients as well as the covariance of the error terms across the equations were jointly not equal to zero, $\chi 2(56)=$ $314.93, \mathrm{p}=.000$ (Table 11). Similarly, Wald's chi-squared statistic for the ordered probit model was statistically significant; thereby indicating that all gradient coefficients were jointly not equal to zero, $\chi 2(8)=65.82, p=.000$ (Table 12). The OLS model used in the study had a statistically significant $\mathrm{F}$ statistic, $\mathrm{F}(8,123)=25.38, \mathrm{p}=.000, \mathrm{R}^{2}=0.66$ (Table 13). Therefore, the results of the three models implied that the hypothesis that there is no statistically significant influence of selected socio-economic factors on the adoption of SATs was rejected $(p<.05)$.

Table 11: Multivariate probit model results for the socio-economic factors

\begin{tabular}{|c|c|c|c|c|c|c|c|}
\hline & MMU & AGF & PP & MC & RT & $\mathrm{CR}$ & CRI \\
\hline Factors & $\begin{array}{c}\text { Coef } \\
\text { (RSE) }\end{array}$ & $\begin{array}{l}\text { Coef } \\
\text { (RSE) }\end{array}$ & $\begin{array}{c}\text { Coef } \\
\text { (RSE) }\end{array}$ & $\begin{array}{l}\text { Coef } \\
\text { (RSE) }\end{array}$ & $\begin{array}{c}\text { Coef } \\
\text { (RSE) }\end{array}$ & $\begin{array}{l}\text { Coef } \\
\text { (RSE) }\end{array}$ & $\begin{array}{l}\text { Coef } \\
\text { (RSE) }\end{array}$ \\
\hline Age (yrs) & $\begin{array}{l}-.039 \\
(.020)\end{array}$ & $\begin{array}{c}.004 \\
(.011)\end{array}$ & $\begin{array}{c}-.043 \\
(.011)\end{array}$ & $\begin{array}{c}.012 \\
(.014)\end{array}$ & $\begin{array}{c}-.030 \\
(.025)\end{array}$ & $\begin{array}{c}-.003 \\
(.018)\end{array}$ & $\begin{array}{l}.004 \\
(.012)\end{array}$ \\
\hline Sex & $\begin{array}{l}.107 \\
(.377)\end{array}$ & $\begin{array}{c}.190 \\
(.264)\end{array}$ & $\begin{array}{c}.377 \\
(.267)\end{array}$ & $\begin{array}{l}-.438 \\
(.348)\end{array}$ & $\begin{array}{c}.387 \\
(.394)\end{array}$ & $\begin{array}{c}.282 \\
(.297)\end{array}$ & $\begin{array}{l}.220 \\
(.260)\end{array}$ \\
\hline HH size & $\begin{array}{l}-.045 \\
(.093)\end{array}$ & $\begin{array}{l}-.053 \\
(.070)\end{array}$ & $\begin{array}{c}.052 \\
(.064)\end{array}$ & $\begin{array}{l}.226 * * \\
(.074)\end{array}$ & $\begin{array}{c}.163 \\
(.085)\end{array}$ & $\begin{array}{l}-.138 \\
(.074)\end{array}$ & $\begin{array}{l}-.064 \\
(.077)\end{array}$ \\
\hline Ed. level (yrs) & $\begin{array}{c}.042 \\
(.085)\end{array}$ & $\begin{array}{l}.138 * * \\
(.060)\end{array}$ & $\begin{array}{l}.200^{*} \\
(.058)\end{array}$ & $\begin{array}{c}.078 \\
(.084)\end{array}$ & $\begin{array}{l}.215^{* *} \\
(.096)\end{array}$ & $\begin{array}{l}.170^{*} \\
(.058)\end{array}$ & $\begin{array}{c}.004 \\
(.055)\end{array}$ \\
\hline Land size & $\begin{array}{c}.074 \\
(.165)\end{array}$ & $\begin{array}{l}.291^{*} \\
(.113)\end{array}$ & $\begin{array}{c}.065 \\
(.114)\end{array}$ & $\begin{array}{l}.309 * * \\
(.143)\end{array}$ & $\begin{array}{l}.167^{* *} \\
(.165)\end{array}$ & $\begin{array}{l}.402 * \\
(.127)\end{array}$ & $\begin{array}{l}.435^{*} \\
(.112)\end{array}$ \\
\hline Log income & $\begin{array}{l}1.439 \\
(.903)\end{array}$ & $\begin{array}{c}-.520 \\
(.661)\end{array}$ & $\begin{array}{c}-.733 \\
(.694)\end{array}$ & $\begin{array}{l}1.367 \\
(.957)\end{array}$ & $\begin{array}{c}-.794 \\
(1.014)\end{array}$ & $\begin{array}{c}.331 \\
(.589)\end{array}$ & $\begin{array}{c}-.426 \\
(.718)\end{array}$ \\
\hline Hired labour & $\begin{array}{l}-.420 \\
(.398)\end{array}$ & $\begin{array}{c}.039 \\
(.319)\end{array}$ & $\begin{array}{c}.217 \\
(.333)\end{array}$ & $\begin{array}{l}-.211 \\
(.387)\end{array}$ & $\begin{array}{c}-.313 \\
(.544)\end{array}$ & $\begin{array}{l}-.215 \\
(.340)\end{array}$ & $\begin{array}{c}.583 \\
(.336)\end{array}$ \\
\hline TLUs & $\begin{array}{c}1.041^{* *} \\
(.358)\end{array}$ & $\begin{array}{c}.031 \\
(.056)\end{array}$ & $\begin{array}{l}.213 * * \\
(.055)\end{array}$ & $\begin{array}{c}.043 \\
(.049)\end{array}$ & $\begin{array}{c}.094 \\
(.085)\end{array}$ & $\begin{array}{c}.114 \\
(.062)\end{array}$ & $\begin{array}{c}.091 \\
(.067)\end{array}$ \\
\hline
\end{tabular}

Sample size $=132 \quad$ Wald $\chi^{2}(56)=314.93 \quad$ Log likelihood $=-391.54 \quad$ Prob. $>\chi^{2}=.000$

Source. Own survey (2019)

Note: RSE are the Robust Standard Errors (presented in parentheses). MMU=Manure Making and Utilization, AGF=Agroforestry, PP=Pit-planting, MC=Mulching, RT=Reduced Tillage, CR=Crop Rotation and CRI=Crop Residue Incorporation

$*$ and $* *$ indicate the statistical significance at $\mathrm{p}<.01$ and $\mathrm{p}<.05$ respectively

Particularly, the study revealed that the socio-economic factors which significantly influenced the adoption of SATs were household size, education level, arable land size and number of livestock owned (as measure in TLUs). The results also implied that by holding other independent variables constant in the three models, the influence of age, sex, income level and 
sources of farm labour was too insignificant at $95 \%$ confidence interval; despite the contribution of the five factors to the differences between the adopters and non-adopters (as discussed in subsection 3.1). The results also indicated that an increase in the size of small-scale households made adoption of mulching more likely (Table 11). However, household size had an insignificant influence on adoption levels of the SATs (in terms of both the number of SATs and acreage under the technologies); as it only predicted the probability of mulching adoption. In additional to the common farm operations, mulching involves some labour-intensive and timeconsuming activities such as collection, preserving and laying of mulch (Abdul-Hanan et al., 2014). These activities are usually allocated to or shared among household members at a relatively lower cost than that of hired labour. Therefore, the larger the household size the higher the likelihood of adopting mulching (D'souza, Cyphers \& Phipps, 1993); Tey, 2013).

\section{Table 12: Ordered probit model results for the socio-economic factors}

\begin{tabular}{|c|c|c|c|c|c|c|c|c|}
\hline \multirow{3}{*}{ Factors } & & & \multicolumn{6}{|c|}{ Average marginal effects } \\
\hline & \multicolumn{2}{|c|}{ Coefficients } & \multicolumn{2}{|c|}{$\operatorname{Prob}(\mathrm{Y} \leq 2 \mid \mathrm{X})$} & \multicolumn{2}{|c|}{$\operatorname{Prob}(3 \leq \mathrm{Y} \leq 4 \mid \mathrm{X})$} & \multicolumn{2}{|c|}{$\operatorname{Prob}(\mathrm{Y} \geq 5 \mid \mathrm{X})$} \\
\hline & Coef & RSE & Coef & RSE & Coef & RSE & Coef & RSE \\
\hline Age & -.06 & .100 & .002 & .003 & -.001 & .001 & -.001 & .002 \\
\hline Sex & .267 & .238 & -.104 & .091 & .037 & .032 & .066 & .061 \\
\hline Household size & .060 & .068 & -.023 & .026 & .009 & .010 & .015 & .017 \\
\hline Education level & $.132 * *$ & .060 & $-.051 * *$ & .023 & .019 & .011 & $.032 * *$ & .014 \\
\hline Farm distance & -.046 & .128 & .018 & .050 & -.007 & .019 & -.011 & .031 \\
\hline Land size & $.366^{*}$ & .114 & $-.142 *$ & .044 & $.054 * *$ & .023 & $.089 *$ & .029 \\
\hline Income $(\log )$ & -.220 & .600 & .086 & .234 & -.032 & .090 & -.072 & .058 \\
\hline Hired labour & .347 & .065 & -.133 & .108 & .042 & .030 & .091 & .081 \\
\hline TLUs & $.160 * *$ & .065 & $-.062 * *$ & .025 & $.023 * *$ & .011 & $.039 * *$ & .016 \\
\hline
\end{tabular}

Sample size $=132$

Wald $\chi 2(8)=65.82$

Prob. $>\chi 2=.000$

Log pseudolikelihood $=-102.852$

Pseudo $\mathrm{R}^{2}=.268$

Source. Own survey (2019)

Note: RSEs are Robust Standard Errors. $\operatorname{Prob}(\mathrm{Y} \leq 2 \mid \mathrm{X}), \operatorname{Prob}(3 \leq \mathrm{Y} \leq 4 \mid \mathrm{X}), \operatorname{Prob}(\mathrm{Y} \geq 5 \mid \mathrm{X})$ show the probabilities for low adoption (1 and 2 SATs), average adoption (3 and 4 SATs) and high adoption (5, 6 and 7 SATs) categories $*$ and $* *$ indicate the statistical significance at $\mathrm{p}<.01$ and $\mathrm{p}<.05$ respectively

In terms of education level, the study showed that the farming households whose heads had relatively more years of formal schooling were more likely to be agroforestry, pit-planting, reduced tillage and crop rotation adopters (Table 11). The findings revealed that an increase in the years of formal schooling by one year resulted in a reduction of the likelihood of being in a 
International Journal of Agriculture and Environmental Research

ISSN: 2455-6939

Volume: 06, Issue: 02 "March-April 2020"

low adopters category (those with zero to two SATs) by 5\% and an increase in the probability of being in a high adopters category (those with five to seven SATs) by 3\% (Table 12). Further, a one year increase in the formal schooling years increased the area under SATs by 0.1 acre (Table 13). Since the technological attributes and rationale relating to the SATs require a great deal of mastery, farmers with a relatively higher education level are more likely to understand and use the technologies as compared to their less educated counterparts (Abdulai \& Huffman, 2014). Education also helps to improve farmers' capacity to effectively seek and evaluate relevant information on SATs; as well as to appreciate the benefits of the technologies (Kassie et al., 2015; Murendo et al., 2016). Therefore, formal education should be promoted across all schoolgoing ages in Mzimba South since most of the small-scale maize farming households in the area depend on the household members as the main source of farm labour.

Table 13: OLS model results for the socio-economic factors

\begin{tabular}{lcccc}
\hline Explanatory factors & Coefficients & Standard errors & t-value & $\mathrm{P}>|\mathrm{t}|$ \\
\hline Age & -.012 & .007 & -.27 & .784 \\
Sex & .147 & .174 & .84 & .402 \\
Household size & -.086 & .044 & -1.96 & .059 \\
Education level & $.108^{* *}$ & .035 & 3.05 & .003 \\
Land size (Arable) & $.602^{* *}$ & .073 & 8.26 & .000 \\
Log income & .056 & .439 & .13 & .899 \\
Labour (Hired) & -.236 & .211 & -1.12 & .266 \\
Total livestock units (TLUs) & $.135^{* *}$ & .033 & 4.08 & .000 \\
\hline Sample size = 132 & $\mathrm{F}(8,123)=25.38$ & & Prob $>\mathrm{F}=.000$ \\
$\mathrm{R}^{2}=.656$ & Adjusted $\mathrm{R}^{2}=.626$ & & \\
\hline $\begin{array}{l}\text { Source. Own survey (2019) } \\
* \text { and } * * \text { indicate the statistical significance at } \mathrm{p}<.01 \text { and } \mathrm{p}<.05 \text { respectively }\end{array}$
\end{tabular}

With respect to size of arable land, the results showed that an increase in acreage made it more likely for the households to adopt agroforestry, mulching, reduced tillage, crop rotation and crop residues incorporation in Mzimba South (Table 11). The ordered probit model analysis indicated that an increase in area of arable land by one acre made it less likely for a household to be a low adopter by $14 \%$, and increased its likelihood to be an average adopter and a high adopter by $5 \%$ and $9 \%$ respectively (Table 12). In addition, OLS model results showed that a one acre increase in arable land led to an increase of land used for SATs by 0.6 acre (Table 13). These findings are similar to those of a study by Murendo et al. (2016), in which farmers with relatively larger land 
International Journal of Agriculture and Environmental Research

ISSN: 2455-6939

Volume: 06, Issue: 02 "March-April 2020"

holdings were more likely to adopt SATs due to their high level of flexibility to allocate some portions to sustainable cropping. However, rapidly growing population in Malawi continues to reduce per capita land holdings; as a result of fragmentation of customary arable land into smaller plots (Kateta, Kabambe, Lowole \& Nalivata, 2015). Therefore, promotion of SATs in maize farming should be complemented by the intensification strategies that ensure optimal crop productivity per given area of land.

As regards livestock ownership, the study established that an increase in the number of livestock owned (as measured TLUs) increased farmers' probability of adopting manure and pit-planting; since the two SATs depend on animal manure (Table 11). Positive correlations of TLUs and manure acreage, $\mathrm{r}(130)=0.68, \mathrm{p}=.000$, and that of TLUs and pit-planting acreage, $\mathrm{r}(130)=$ $0.63, \mathrm{p}=.000$ further signified the dependency of farmers on animal manure in Mzimba South. The findings also showed that an increase in the livestock population owned by one unit reduced the likelihood of being a low adopter by $6 \%$, and increased the probability of being an average adopter and a high adopter by $2 \%$ and $3 \%$ respectively (Table 12). The OLS model results indicated that a one-unit increase in the number of livestock increased acreage under SATs by 0.1 (Table 13). These results are consistent with those of Kassie et al. (2013); in which adoption of SATs in most of African countries was attributed to increased quantities of animal manure, and increased level of investment in sustainable farming as a result of livestock sells. Therefore, interventions for promoting SATs in Mzimba South should also aim at enhancing farmers' capacity in increasing livestock population and diversifying the types of manure (such as composite and green manure) beside animal manure.

\section{CONCLUSION AND RECOMMENDATIONS}

The study established that there were significant differences in the socio-economic characteristics between the adopters and non-adopters on the basis of age, household size, education level, arable land size, farming experience, household income, livestock ownership and sex of household heads. The findings revealed that the adoption of SATs was positively influenced by the household size, education level, arable land size and number of livestock units owned. The results imply that the Government of Malawi and other relevant stakeholders in the agriculture sector should promote trainings of all categories of small-scale producers on the implementation of the seven SATs. The trainings should be complemented by crop intensification strategies that ensure optimal maize production per given area of arable land. In addition, the stakeholders should promote livestock multiplication and effective crop-livestock integration interventions to increase quantities of organic manure and reduce competition for crop biomass between crops and livestock enterprises. Efforts should also be made to enhance 
International Journal of Agriculture and Environmental Research

ISSN: 2455-6939

Volume: 06, Issue: 02 "March-April 2020"

the producers' capacity in diversifying the types of manure (such as composite and green manure) beside animal manure.

\section{REFERENCES}

Abdulai, A., \& Huffman, W. (2014). The adoption and impact of soil and water conservation technology: An endogenous switching regression application. Land Economics, 90(1), 26-43. doi: $10.3368 / \mathrm{le} .90 .1 .26$

Abdul-Hanan, A., Ayamga, M., \& Donkoh, S. A. (2014). Smallholder adoption of soil and water conservation techniques in Ghana. African Journal of Agricultural Research, 9(5), 539546.

Azari, H., Parks, D., \& Xia, L. (2012). Random utility theory for social choice. Paper presented at the Advances in Neural Information Processing Systems. Retrieved from https://papers. nips.cc/paper/4735-random-utility-theory-for-social-choice

Barrow, C., Chan, N., \& Masron, T. B. (2010). Farming and other stakeholders in a tropical highland: Towards less environmentaly damaging and more sustainable practices. Journal of Sustainable Agriculture, 34(4), 365-388. doi:10.1080/10440041003680205

Creswell, J. W., Plano Clark, V. L., Gutmann, M. L., \& Hanson,W. E. (2003). Advance mixed methods research designs. In A.Tashakkori \& C. Teddlie (Eds.), Handbook of mixed methods in social and behavioral research (pp. 209-240). Thousand Oaks, CA: Sage.

D'souza, G., Cyphers, D., \& Phipps, T. (1993). Factors affecting the adoption of sustainable agricultural practices. Agricultural and Resource Economics Review, 22(2), 159-165.

Dorfman, J. H. (1996). Modeling multiple adoption decisions in a joint framework. American Journal of Agricultural Economics, 78(3), 547-557.

Emuh, F., \& Ofuoku, A. (2011). Analysis of the adoption of farm yard manure among smallscale farmers in Delta state, Nigeria. International Journal of Science and Nature, 2(4), 813-830.

Food and Agriculture Organization. (2017). Retrieved from http://www.fao.org/nr/water/ aquastat/ data/query/index.html?lang=en

Friedrich, T., Derpsch, R., \& Kassam, A. (2012). Overview of the global spread of conservation agriculture [Special issue]. The Journal Of Field Actions, 6(6). Retrieved from https://journals.openedition.org/factsreports/1941 
International Journal of Agriculture and Environmental Research

ISSN: 2455-6939

Volume: 06, Issue: 02 "March-April 2020"

Goeb, J. (2013). Conservation Farming Adoption and Impact among First Year Adopters in Central Zambia. Indaba Agricultural Policy Research Institute Working Paper 80. Lusaka. Zambia. Retrieved from http://www.iapri.org.zm

Kassie, M., Jaleta, M., Shiferaw, B., Mmbando, F., \& Mekuria, M. (2013). Adoption of interrelated sustainable agricultural practices in smallholder systems: Evidence from rural Tanzania. Technological Forecasting and Social Change, 80(3), 525-540.

Kassie, M., Teklewold, H., Jaleta, M., Marenya, P., \& Erenstein, O. (2015). Understanding the adoption of a portfolio of sustainable intensification practices in eastern and southern Africa. Land Use Policy, 42, 400-411.

Kassie, M., Zikhali, P., Manjur, K., \& Edwards, S. (2009). Adoption of sustainable agriculture practices: Evidence from a semi-arid region of Ethiopia (Environment for Development Discussion Paper No. 09-12). Retrieved from http://www.rff.org/files/sharepoint/ WorkImages/Download/EfD-DP-09-12

Kateta, S. Y., Kabambe, V., Lowole, M. W., \& Nalivata, P. C. (2015). Production practices of potato (Solanum tuberosum L.) by farmers in Mzimba District, Northern Malawi. African Journal of Agricultural Research, 10(8), 797-802.

Lambert, O., \& Ozioma, A. F. (2012). Adoption of improved agroforestry technologies among contact farmers in Imo state, Nigeria. Asian Journal of Agriculture and Rural Development, 2(1), 1-9.

Lovo, S. (2016). Tenure insecurity and investment in soil conservation. Evidence from Malawi. World Development, 78, 219-229.

MacRae, R. J., Hill, S. B., Henning, J., \& Mehuys, G. R. (1989). Agricultural science and sustainable agriculture: A review of the existing scientific barriers to sustainable food production and potential solutions. Biological agriculture and horticulture, 6(3), 173219.

Manski, C. F. (1977). The structure of random utility models. Theory and decision, 8(3), 229254.

McKelvey, R. D., \& Zavoina, W. (1975). A statistical model for the analysis of ordinal level dependent variables. Journal of mathematical sociology, 4(1), 103-120.

M'mbelwa District Council. (2017). Socio-economic Profile (SEP). Lilongwe, Malawi: Ministry of Local Government and Rural Development. Retrieved from https://localgovt.gov.mw/ 
International Journal of Agriculture and Environmental Research

ISSN: 2455-6939

Volume: 06, Issue: 02 "March-April 2020"

publications/social-economic-profiles-seps/mzimba-1/31-m-mbelwa-district-socialecono- mic-profile-2017-2022

Mugenda, O. M., \& Mugenda, A. G. (2003). Research methods: Quantitative and qualitative approaches. Nairobi, Kenya: Acts Press.

Murendo, C., Gwara, S., Mpofu, N., Pedzisa, T., Mazvimavi, K., \& Chivenge, P. (2016, September 23-26). The adoption of a portfolio of sustainable agricultural practices by smallholder farmers in Zimbabwe. Paper presented at the $5^{\text {th }}$ International Conference of the African Association of Agricultural Economists, Addis Ababa, Ethiopia. Retrieved from

https://ageconsearch.umn.edu/bitstream/246383/2/90.\%20Sustainable\%20practices\%20in $\% 20$ Zimbabwe

Musara, J. P., Chimvuramahwe, J., \& Borerwe, R. (2012). Adoption and Efficiency of Selected Conservation Farming Technologies in Madziva Communal Area, Zimbabwe: A Transcendental Production Function Approach. Journal's URL: www. bepls. com, 1(4), $27-38$.

Nassiuma, D. K. (2000). Survey sampling: Theory and methods. Nairobi, Kenya: Nairobi University Press.

Ngwira, A., Johnsen, F. H., Aune, J. B., Mekuria, M., \& Thierfelder, C. (2014). Adoption and extent of conservation agriculture practices among smallholder farmers in Malawi. Journal of Soil and Water Conservation, 69(2), 107-119.

Njoloma, J. P., Sileshi, W. G., Sosola, B. G., Nalivata, P. C., \& Nyoka, B. I. (2016). Soil fertility status under smallholder farmers' fields in Malawi. Afr. J. Agric. Res, 11, 1679-1687.

Odendo, M., Obare, G., \& Salasya, B. (2011). What factors influence the speed of adoption of Soil fertility management technologies? Evidence from Western Kenya. Journal of Development and Agricultural Economics, 3(13), 627-637.

Prager, K., \& Posthumus, H. (2010). Socio-economic factors influencing farmers' adoption of soil conservation practices in Europe.Human Dimensions of Soil and Water Conservation, 12, 203-223.

Pretty, J., Toulmin, C., \& Williams, S. (2011). Sustainable intensification in African agriculture. International Journal of Agricultural Sustainability, 9(1), 5-24. doi:10.3763/ijas.2010.05 
Sosola, B. G., Akinnifesi, F. K., Sileshi, G., \& Ajayi, O. (2011). Evergreen Agriculture: extension manual for farmers and extension workers in Malawi. Lilongwe, Malawi: World Agroforestry Centre.

Teklewold, H., Kassie, M., \& Shiferaw, B. (2013). Adoption of multiple sustainable agricultural practices in rural Ethiopia. Journal of agricultural economics, 64(3), 597-623.

Tey, Y. S. (2013). The adoption of sustainable agricultural practices: an integrative approach for Malaysian vegetable farmers (Doctoral dissertation). Retrieved from https://digital. library.adelaide.edu.au/dspace/bitstream/2440/83762/8/02

Thierfelder, C., Ngwira, A., Eash, N., \& Lambert, D. M. (2013). Risk and maize-based cropping systems for smallholder Malawi farmers using conservation agriculture technologies. Experimental Agriculture, 49(4), 483-503. 